\title{
Proteinuria in Nondiabetic Patients: Clinical Significance
}

\author{
${ }^{1}$ Vijay Viswanathan, ${ }^{2}$ A Anitha Rani
}

\begin{abstract}
Proteinuria is a major health care problem, which affects millions of peoples globally. It is a characteristic of Diabetic Nephropathy and a strong indicator of kidney disease and renal dysfunction. It occurs in different forms with varied degree of severity. Proteinuria can be classified based on the amount and type of the protein and the pathological damage. Process involved in proteinuria is complex and multifactorial which includes tubular absorption, hemodynamics of glomerular and diffusion gradients. A continuous function of kidney is necessary for regular urine formation. In normal physiological condition urine is free of protein and this action was efficiently performed by nephrons in the kidneys. Nephrons play a major role in filtration and reabsorption. Thus kidney disease is associated with the malfunction of reabsorption mechanism.
\end{abstract}

Keywords: Clinical, Diabetes, Glomerular filtration, Proteinuria, Renal function.

How to cite this article: Viswanathan V, Rani AA. Proteinuria in Nondiabetic Patients: Clinical Significance. Hypertens J 2016;2(3):118-123.

\section{Source of support: Nil \\ Conflict of interest: None}

\section{INTRODUCTION}

Proteinuria is recognized as an independent risk factor for cardiovascular disease (CVD) and renal disease and as a predictor of end organ damage. ${ }^{1}$ In particular, detection of an increase in protein excretion is known to have both diagnostic and prognostic value in the initial detection and confirmation of renal disease. ${ }^{2}$ Further, it has been shown to be an independent risk factor for the progression of kidney disease rather than simply being a marker for glomerular dysfunction. ${ }^{3}$ It is a common clinical finding in primary care practice. It is defined as urinary protein excretion of greater than $150 \mathrm{mg}$ of protein/day, of which approximately $20 \mathrm{mg}$ is albumin. The daily excretion of more than $3.5 \mathrm{gm}$ of protein is called nephrotic range of proteinuria. Urinary protein excretion in healthy persons

\footnotetext{
${ }^{1}$ Head and Chief, ${ }^{2}$ Post Doctoral Research Fellow

${ }^{1}$ Department of Diabetology, M.V. Hospital for Diabetes and Diabetes Research Centre, Chennai, Tamil Nadu, India

${ }^{2}$ Department of Kidney, M.V. Hospital for Diabetes and Diabetes Research Centre, Chennai, Tamil Nadu, India

Corresponding Author: Vijay Viswanathan, Head and Chief Department of Diabetology, M.V. Hospital for Diabetes and Diabetes Research Centre, Chennai, Tamil Nadu, India, e-mail: researchcommunication@mvdiabetes.com
}

varies considerably and may reach proteinuric levels under several circumstances.

\section{PROTEINURIA}

Proteinuria denotes a sign of glomerular diseases and represents a marker of injury to the glomerular permeability barrier. Ultrafiltered proteins are partly lost in urine (proteinuria) and partly absorbed by endocytosis in the proximal tubules. During periods of heavy proteinuria, the ultrafiltered proteins accumulate in lysosomes in the proximal tubular cells, causing cell disruption and injury. ${ }^{4,5}$ Further data suggest that protein overload may also directly contribute to podocyte injury and eventual glomerulosclerosis. ${ }^{6}$ In addition, proteinuria, even at a subnephrotic range, is a well-known risk factor for CV mortality and morbidity and is strongly associated with the progression of kidney disease. Urinary protein excretion has been used as a surrogate end point for therapeutic interventions of chronic kidney disease (CKD) where decreasing proteinuria would delay the progression of CKD. ${ }^{7}$

Proteinuria is preceded by stages of excessive glomerular filtration and of microalbuminuria, which signals an increased risk of progression to overt nephropathy. A progressive increase in proteinuria subsequently leads to a variable decline in renal function. ${ }^{8}$ End-stage renal disease (ESRD) in several glomerular diseases is histologically characterized by glomerulosclerosis and tubulointerstitial fibrosis.

Glomerular hypertension in both diabetic and nondiabetic chronic nephropathies leads to increased glomerular permeability and excessive protein filtration. A large number of experimental studies have demonstrated that chronic nephropathies share common pathogenic mechanisms that contribute to renal disease progression, independently of the original etiology. The common pathway of renal injury includes systemic hypertension, increased glomerular pressure and tubular protein overload, secondary tubulointerstitial inflammation, and fibrosis. ${ }^{9,10}$ The reduction of proteinuria is assumed to play a key role in the treatment of renal disease and has a main impact on slowing progression of chronic renal disease. ${ }^{11}$ Proteinuria is also an independent risk factor for the development of CVDs in diabetic and nondiabetic renal disease (NDRD). Patients with microalbuminuria and a normal or small reduced 
Proteinuria in Nondiabetic Patients: Clinical Significance

glomerular filtration rate have more frequent coronary events and death. ${ }^{12,13}$

\section{CLASSIFICATION OF PROTEINURIA}

Proteinuria can be classified into three categories, such as overflow proteinuria, tubular proteinuria, and glomerular proteinuria (Table 1).

\section{Overflow Proteinuria}

Low-molecular-weight proteins filtered by the glomerulus are almost entirely reabsorbed in the proximal tubule. During states of increased low-molecular-weight protein production and subsequent filtration, the amount of filtered protein exceeds tubular reabsorptive capacity, leading to proteinuria. Most often, this is a result of the immunoglobulin overproduction that occurs in multiple myeloma. The resultant light-chain immunoglobulin fragments (Bence Jones proteins) produce a monoclonal spike in the urine electrophoretic pattern. ${ }^{14}$ This can be detected in the urine because of the limited reabsorptive capacity of the proximal tubule.

\section{Tubular Proteinuria}

Tubular proteinuria occurs when tubulointerstitial disease prevents the proximal tubule from reabsorbing low-molecular-weight proteins (part of the normal glomerular ultrafiltrate). When a patient has tubular disease, usually less than $2 \mathrm{gm}$ of protein is excreted in 24 hours. Tubular diseases include hypertensive nephrosclerosis and tubulointerstitial nephropathy caused by nonsteroidal anti-inflammatory drugs.

\section{Glomerular Proteinuria}

Glomerular proteinuria is a sensitive marker for glomerular disease. It is the most common cause of pathologic proteinuria. ${ }^{15}$ Several glomerular abnormalities alter the permeability of the glomerular basement membrane, resulting in urinary loss of albumin and immunoglobulins. ${ }^{15}$ Glomerular malfunction can cause large protein losses; urinary excretion of more than 2 gm per 24 hours is usually a result of glomerular disease.

\section{Pathophysiological Mechanism in Proteinuria}

Protein in urine can sometimes be a sign of kidney disease, as well as other health problems. Protein is one of the major building blocks of the body along with fats and sugars. The correct proportion of the protein is important in our diets, for growth and repair mechanism.

Healthy kidneys filter only traces of protein from blood into the urine as most protein molecules are large for the filters (glomeruli). Thus, it is not usual to lose
Table 1: Pathophysiology in proteinuria

\begin{tabular}{|c|c|c|}
\hline Type & Pathophysiology & Causes \\
\hline $\begin{array}{l}\text { Overflow } \\
\text { proteinuria }\end{array}$ & $\begin{array}{l}\text { Increased production } \\
\text { of low-molecular- } \\
\text { weight protein }\end{array}$ & $\begin{array}{l}\text { Monoclonal } \\
\text { gammopathy leukemia }\end{array}$ \\
\hline $\begin{array}{l}\text { Tubular } \\
\text { proteinuria }\end{array}$ & $\begin{array}{l}\text { Decreased tubular } \\
\text { resorption of protein in } \\
\text { glomerular filtrate }\end{array}$ & $\begin{array}{l}\text { Tubular or interstitial } \\
\text { disease }\end{array}$ \\
\hline $\begin{array}{l}\text { Glomerular } \\
\text { proteinuria }\end{array}$ & $\begin{array}{l}\text { Increased glomerular } \\
\text { permeability to protein }\end{array}$ & $\begin{array}{l}\text { Primary or secondary } \\
\text { glomerulopathy }\end{array}$ \\
\hline $\begin{array}{l}\text { Postural } \\
\text { proteinuria }\end{array}$ & $\begin{array}{l}\text { Abnormal protein } \\
\text { excretion in the } \\
\text { upright posture, } \\
\text { with normal urinary } \\
\text { protein excretion } \\
\text { in recumbency, } \\
\text { probably due to } \\
\text { exaggerated systemic } \\
\text { and glomerular } \\
\text { hemodynamic } \\
\text { responses in the } \\
\text { upright posture }\end{array}$ & $\begin{array}{l}\text { Otherwise normal } \\
\text { subjects with } \\
\text { structurally normal } \\
\text { kidneys. Occasionally } \\
\text { might mark beginning } \\
\text { of more serious renal } \\
\text { disease }\end{array}$ \\
\hline $\begin{array}{l}\text { "Admixture" } \\
\text { proteinuria }\end{array}$ & $\begin{array}{l}\text { Gross hematuria with } \\
\text { tests for urinary protein } \\
\text { detecting protein } \\
\text { present in blood mixed } \\
\text { with urine. No renal } \\
\text { pathology }\end{array}$ & $\begin{array}{l}\text { Urological causes of } \\
\text { hematuria, such as } \\
\text { calculi and cancer. Daily } \\
\text { protein excretion usually } \\
<1 \mathrm{gm} \text {. If the random } \\
\text { protein to creatinine } \\
\text { ratio is }>1.0 \text {, underlying } \\
\text { glomerular disease is } \\
\text { the likely cause of gross } \\
\text { hematuria }\end{array}$ \\
\hline $\begin{array}{l}\text { "Physiologic"/ } \\
\text { transient } \\
\text { proteinuria }\end{array}$ & $\begin{array}{l}\text { Probably due to } \\
\text { transient glomerular } \\
\text { hemodynamic changes }\end{array}$ & $\begin{array}{l}\text { Exercise, fever, } \\
\text { congestive heart failure }\end{array}$ \\
\hline
\end{tabular}

protein to the urine. Proteinuria develops when protein is filtered through the glomeruli. There are several proteins filtered in the urine, but the most relevant to kidney disease is albumin. Healthy kidneys excrete less than $150 \mathrm{gm}$ of protein/day, of which approximately $20 \mathrm{gm}$ is albumin. When this level exceeds, the condition is known as microalbuminuria. It is defined as excretion of 30 to $300 \mathrm{gm}$ of albumin/day and is an early and sensitive marker of diabetic nephropathy. ${ }^{16-18}$ Microalbuminuria is associated with an increased risk of CVD in patients with and without diabetes and/or hypertension. 15,19,20 The presence of protein in the urine is a warning signal for kidney function.

\section{Genetic Predisposition}

Genetic factors play an important role in the development of renal disease and proteinuria. Genetic predispositions are found in both congenital and acquired renal diseases. In recent years, several mutations in genes expressed in glomerular cells and especially in podocytes are found in congenital and early-onset proteinuria. ${ }^{21}$ Apart from its role in congenital or early-onset proteinuria, genetic factors play an important role in acquired renal diseases. 
They influence both severity of proteinuria and progression of renal disease. For example, diabetic nephropathy is associated with loci on chromosomes 10 and 18, and susceptibility to develop familial immunoglobulin A nephropathy has been linked to loci on chromosomes $2,4,6$, and $17^{22-24}$

\section{Symptoms and Cause of Proteinuria}

Generally, there are no symptoms for proteinuria. If the protein loss is heavy, the urine has a frothy appearance and would most likely be associated with other symptoms, e.g., edema, where there is an excess of water in the body tissues.

The common causes of benign proteinuria are dehydration, emotional stress, fever, heat injury, inflammatory process, intense activity, and most acute illness. Further, glomerular diseases, such as glomerulonephritis and urinary tract infection can also cause proteinuria. Proteinuria can also be a symptom of other medical conditions, such as congestive heart failure, a first warning of eclampsia in pregnancy. Temporary proteinuria may occur after vigorous exercise or during high fever. In children, proteinuria can be detected later in the day, but not in the morning. This is known as orthostatic proteinuria, and it is usually harmless.

Prolonged proteinuria with the warning signal, such as large amounts of protein in the urine, blood in the urine, abnormal kidney tests like creatinine or estimated glomerular filtration rate (GFR), and high blood pressure are more likely to lead to kidney problems. High proteinuria ( $>2-3 \mathrm{gm}$ per day, or a protein/creatinine ratio of 200-300 or more) usually needs further investigation to find out the cause. In the absence of the above warning signals, it is necessary to monitor kidney tests, urine tests, and blood pressure occasionally. Patients with proteinuria are more likely to suffer from heart disease. Thus, it is important to check blood pressure, cholesterol (usually higher in patients with proteinuria), and factors which cause heart disease, such as smoking and obesity.

\section{Risk Factors for Proteinuria}

The two most common risk factors for proteinuria are diabetes and hypertension. Both diabetes and high blood pressure can cause damage to the kidneys, which leads to proteinuria. In patients with essential hypertension and in those with diabetes mellitus, the presence of increased amounts of urinary protein or albumin has been shown to be an important and independent risk for an increased incidence of CV morbidity and mortality.

Other than diabetes or hypertension, proteinuria can also be caused due to medications, trauma, toxins, infections, and immune system disorders, such as multiple myeloma and amyloidosis. Other risk factors include race and ethnicity, obesity, age ( $>65$ years), family history of kidney disease, and preeclampsia. Proteinuria is regarded as the most acceptable predictive variable in the prognosis of nondiabetic chronic renal disease progression. ${ }^{25}$ Proper interpretation of proteinuria has to be in line with the clinical context, sometimes it may also be based on other factors. For instance, there had been reported cases of complete resolution of microalbuminuria among diabetic subjects who were found to be normoalbuminuria with 48 months of follow-up. ${ }^{26}$ Unfortunately, these proteins' effectiveness as biomarkers suffered from lack of specificity and standardization of the techniques.

\section{Recognition of Nondiabetic Proteinuria}

The diagnosis of diabetic nephropathy is almost always based on clinical grounds and supported by persistent proteinuria, hypertension, and a progressive decline in renal function. ${ }^{27}$ A previous study reported that $50 \%$ of proteinuric type 2 diabetics with typical diabetic nephropathy on biopsy did not have diabetic retinopathy. ${ }^{28}$ Renal biopsy is necessary to diagnose NDRD. However, it is generally agreed that renal biopsy cannot be used as a routine diagnostic test in type 2 diabetic patients with proteinuria. Therefore, it is very important to determine the clinical predictive factors for NDRD in type 2 diabetic patients. Factors clinically associated with NDRD in patients with type 2 diabetes mellitus remain unclear. The clinical clues for NDRD in type 2 proteinuric patients are (i) short duration of diabetes, (ii) rapid loss of renal function, (iii) heavy proteinuria with normal renal function, (iv) significant renal dysfunction with minimal/ normoalbuminuria, (v) active urinary sediment, (vi) gross hematuria, and (vii) absence of retinopathy. ${ }^{29}$

Late age of onset of diabetes, absence of neuropathy, absence of retinopathy, and presence of other systemic diseases are reported as markers of NDRD in different studies. However, it remains unclear which clinical factors have greater value in the prediction of NDRD. As the reported incidence of NDRD in type 2 diabetics is high, it is necessary to predict, diagnose, and treat the concurrent glomerular diseases because of the prognostic and therapeutic importance. ${ }^{30}$ So far, only few such studies had been published from India.

\section{Diagnosis and Treatment of Proteinuria}

Protein in the urine is not usually obvious, but can be detected by a simple urine dipstick testing; spot urine specimen analysis, timed urine collection, and the sulfosalicylic acid test are the most commonly employed tests. Proteinuria is not a specific disease; hence the treatment depends on identifying and managing its underlying cause. If that 
cause is kidney disease, appropriate medical management is essential. Untreated CKD can lead to kidney failure. In mild or temporary proteinuria, treatment may not be necessary. Proteinuria is a risk factor for the progression of CKD and is associated with adverse CV outcomes. Controlling blood pressure particularly with strongly antiproteinuric agents slows the progression of CKD and delays/prevents $\mathrm{CV}$ outcomes. Angiotensin-converting enzyme inhibitors (ACEI) and angiotensin receptor antagonists have a blood pressure-independent antiproteinuric effect and are considered first-line agents in this scenario. ${ }^{31}$ Proper treatment is necessary in patients with chronic disease, such as diabetes and high blood pressure. It is essential to prevent the progressive kidney damage, i.e., is causing the proteinuria.

Angiotensin-converting enzyme inhibitors and controlling blood pressure have greater benefit in patients with more significant degrees of proteinuria. In a metaanalysis, Jafar et al $^{32,33}$ demonstrated that antihypertensive regimens containing ACEI have a significant benefit in delaying progression of NDRD.

In light of the high prevalence of NDRD, it is appropriate for performing renal biopsy in type 2 diabetics with clinical suspicion of NDRD, especially with overt proteinuria with or without retinopathy. Kidney biopsy is helpful in two ways: (i) It differentiates diabetic from nondiabetic glomerulopathy and (ii) knowledge of the underlying cause of proteinuria may play an important role in planning the correct treatment of these patients. Further, early diagnosis of NDRD is crucial as appropriate therapy could prolong renal survival, i.e., patient population.

\section{Clinical Relevance of Proteinuria}

Proteinuria is one of the most reliable predictors of renal disease progression, and many studies have demonstrated that limitation of proteins' glomerular ultrafiltration, either with diet or with antihypertensive medication, slows renal disease progression. ${ }^{34}$ There are clinical evidence showing that the renin-angiotensin system blockade with ACEI or with angiotensin II type 1 receptor antagonists slows renal damage progression in diabetic nephropathy and chronic proteinuric nondiabetic nephropathies, ${ }^{35-38}$ and moreover, this renoprotective effect goes beyond simply the reduction of blood pressure levels.

Hypertension is associated with more rapid progression of CKD stages 3 and $4 .{ }^{39}$ Several studies have shown that treating hypertension in patients with CKD and proteinuria may attenuate the decline in GFR. ${ }^{31,40}$ The underlying diagnosis of renal disease, the level of GFR, and level of proteinuria should be evaluated, as well as the complications of decreased GFR, the risk of progression of kidney disease, the presence of clinical CVD and CVD risk factors, and comorbid conditions. ${ }^{41}$

Recently, magnitude of proteinuria has been established as one of the most important risk factors for progression of renal disease. When the protein concentration in the tubular lumen is increased, nuclear factor kappa B translocates to the nucleus of the tubular cells, binds to specific receptors, and enhances gene transcription and generation of inflammatory cytokines including angiotensin, endothelin-1, transforming growth factor beta, regulated upon activation, normal $\mathrm{T}$ cell expressed and secreted (RANTES), monocyte chemoattractant protein 1 , interleukin 1, plasminogen activator inhibitor 1 , and metalloproteinases. ${ }^{4,42}$ This ultimately leads to the presence of interstitial cellular infiltrates and increased matrix protein deposition, which are common observations in renal biopsies of patients with proteinuric renal disease. ${ }^{42}$ Transforming growth factor beta 1 production in renal tubular cells and fibroblasts is increased by angiotensin II, and ACEI have been shown to decrease levels in various forms of kidney disease, and this treatment has been associated with ameliorated damage to the renal interstitium. $^{43}$

Microalbuminuria has been identified as a reliable predictor of developing renal disease in people with diabetic nephropathy and those with renal disease secondary to systemic hypertension. The presence of microalbuminuria predicts worsening of renal disease to overt diabetic nephropathy and increased risk of CVD. Studies have shown the presence of abnormally high urine albumin concentrations in up to $30 \%$ of people with newly diagnosed type 2 diabetes. Of these, approximately 75\% of diabetics will have only microalbuminuria and about $25 \%$ will have overt diabetic nephropathy. ${ }^{44}$ The presence of microalbuminuria in this group of patients also has been associated with increased risk of developing ESRD. In the MICRO-HOPE study, e.g., the risk of progression to diabetic nephropathy over a 5 -year period was $2 \%$ for normal patients, compared with $20 \%$ for microalbuminuric patients. ${ }^{45}$ In another study of diabetics, those with a high urine albumin concentration at study entry were more likely to develop overt proteinuria, and mortality rate was significantly higher. ${ }^{46}$ Microalbuminuria also is a common finding in people with primary hypertension and is a marker for developing renal insufficiency in those people. Microalbuminuria also is significantly more prevalent in hypertensive people than in normotensive ones.

Proteinuria has been linked to established hypertension and renal disease, and it also has been determined that it may precede hypertension. In people, higher rates of urinary albumin excretion in nonhypertensive indi- 
viduals were associated with increased risk of developing hypertension. ${ }^{47}$

\section{Proteinuria as a Biomarker of Kidney Disease}

Several large controlled therapeutic intervention studies during the past years have confirmed that proteinuria is a strong and independent predictor of renal failure in diabetics. ${ }^{48}$ In the Modification of Diet in Renal Disease (MDRD) study, which was designed primarily to evaluate dietary protein restriction and strictblood pressure control in 840 patients with diverse renal diseases, multivariate analysis demonstrated that the degree of proteinuria significantly predicts the decline in GFR. ${ }^{49}$

The presence of filtered high molecular and tubular proteins in urine has been the conventional biomarker indicating impairment and predicting sequence in chronic renal disease. The predictive usefulness of proteinuria was earlier discovered in known cases of type 1 diabetes.

\section{CONCLUSION}

Increased proteinuria would lead to a larger risk for renal failure in the long-term. It is therefore important to carefully examine such patients and follow them up, by controlling their blood pressure, quantitating their proteinuria, and determining their renal function and serum cholesterol. Early recognition and management of proteinuria may result in a delay in the progression to end-stage disease or the successful treatment of the underlying disease. Therefore, proteinuria requires immediate and thorough evaluation. Proteinuria is a well-recognized risk factor for CVD and renal disease; hence, its early pharmacological treatment is a matter of clinical relevance. Little treatment is available to promote the reduction of proteinuria once, i.e., established.

\section{REFERENCES}

1. Barnas U, Schmidt A, Haas M, Kaider A, Tillawi S, Wamser P, Mayer G. Parameters associated with chronic renal transplant failure. Nephrol Dial Transplant 1997;12(Suppl 2):82-85.

2. Ruggenenti P, Perna A, Mosconi L, Pisoni R, Remuzzi G. Urinary protein excretion rate is the best independent predictor of ESRF in non-diabetic proteinuric chronic nephropathies. "Gruppo Italiano di Studi Epidemiologici in Nefrologia" (GISEN). Kidney Int 1998 May;53(5):1209-1216.

3. Burton C, Harris KP. The role of proteinuria in the progression of chronic renal failure. Am J Kidney Dis 1996 Jun;27(6):765775.

4. Remuzzi G, Bertani T. Pathophysiology of progressive nephropathies. N Engl J Med 1998 Nov;339(20):1448-1456.

5. Abbate M, Benigni A, Bertani T, Remuzzi G. Nephrotoxicity of increased glomerular protein traffic. Nephrol Dial Transplant 1999 Feb;14(2):304-312.

6. Abbate M, Zoja C, Morigi M, Rottoli D, Angioletti S, Tomasoni S, Zanchi C, Longaretti L, Donadelli R, Remuzzi G. Transforming growth factor-beta1 is up-regulated by podocytes in response to excess intraglomerular passage of proteins: a central pathway in progressive glomerulosclerosis. Am J Pathol 2002 Dec;161(6):2179-2193.

7. McCormick BB, Sydor A, Akbari A, Fergusson D, Doucette S, Knoll G. The effect of pentoxifylline on proteinuria in diabetic kidney disease: a meta-analysis. Am J Kidney Dis 2008 Sep;52(3):454-463.

8. Klein R, Klein BE, Moss SE. The incidence of gross proteinuria in people with insulin-dependent diabetes mellitus. Arch Intern Med 1991 Jul;151(7):1344-1348.

9. Campbell RC, Ruggenenti P, Remuzzi G. Halting the progression of chronic nephropathy. J Am Soc Nephrol 2002 Nov;13(Suppl 3):S190-S195.

10. Remuzzi G, Ruggenenti P, Perico N. Chronic renal diseases: renoprotective benefits of renin-angiotensin system inhibition. Ann Intern Med 2002 Apr;136(8):604-615.

11. NavarroJF, Mora C, Muros M, García J. Additive antiproteinuric effect of pentoxifylline in patients with type 2 diabetes under angiotensin II receptor blockade: a short-term, randomized, controlled trial. J Am Soc Nephrol 2005 Jul;16(7):2119-2126.

12. FoleyRN,Murray AM,LiS,HerzogCA,McBean AM,EggersPW, Collins AJ. Chronic kidney disease and the risk for cardiovascular disease, renal replacement, and death in the United States Medicare population, 1998 to 1999. J Am Soc Nephrol 2005 Feb;16(2):489-495.

13. Klausen K, Borch-Johnsen K, Feldt-Rasmussen B, Jensen G, Clausen P, Scharling H, Appleyard M, Jensen JS. Very low levels of microalbuminuria are associated with increased risk of coronary heart disease and death independently of renal function, hypertension, and diabetes. Circulation 2004 Jul;110(1):32-35.

14. Longo, DL. Plasma cell disorders. In: Fauci, AS.; Braunwald, E.; Isselbacher, KJ.; Wilson, JD.; Martin, JB.; Kasper, DL.; Hauser, SL.; Long, DL., editors. Harrison's principles of internal medicine. 14th ed. New York: McGraw-Hill; 1998. p. 712-718.

15. Gerstein HC, Mann JF, Yi Q, Zinman B, Dinneen SF, Hoogwerf B, Hallé JP, Young J, Rashkow A, Joyce C, et al. Albuminuria and risk of cardiovascular events, death, and heart failure in diabetic and nondiabetic individuals. JAMA 2001 Jul;286(4):421-426.

16. Remuzzi G, Schieppati A, Ruggenenti P. Clinical practice. Nephropathy in patients with type 2 diabetes. N Engl J Med 2002 Apr;346(15):1145-1151.

17. Viberti GC, Hill RD, Jarrett RJ, Argyropoulos A, Mahmud U, Keen $\mathrm{H}$. Microalbuminuria as a predictor of clinical nephropathy in insulin-dependent diabetes mellitus. Lancet 1982 Jun;1(8287):1430-1432.

18. Parvanova AI, Trevisan R, Iliev IP, Dimitrov BD, Vedovato M, Tiengo A, Remuzzi G, Ruggenenti P. Insulin resistance and microalbuminuria: a cross-sectional, case-control study of 158 patients with type 2 diabetes and different degrees of urinary albumin excretion. Diabetes 2006 May;55(5):14561462.

19. WachtellK,Ibsen H,Olsen MH, Borch-Johnsen K, LindholmLH, Mogensen CE, Dahlöf B, Devereux RB, Beevers G, de Faire U. Albuminuria and cardiovascular risk in hypertensive patients with left ventricular hypertrophy: the LIFE study. Ann Intern Med 2003 Dec;139(11):901-906.

20. Hillege HL, Fidler V, Diercks GF, van Gilst WH, de Zeeuw D, van Veldhuisen DJ, Gans RO, Janssen WM, Grobbee DE, de Jong PE, et al. Urinary albumin excretion predicts cardiovascular and noncardiovascular mortality in general population. Circulation 2002 Oct;106(14):1777-1782. 
21. Tryggvason K, Patrakka J, Wartiovaara J. Hereditary proteinuria syndromes and mechanisms of proteinuria. N Engl J Med 2006 Mar;354(13):1387-1401.

22. Gharavi AG, Yan Y, Scolari F, Schena FP, Frasca GM, Ghiggeri GM, Cooper K, Amoroso A, Viola BF, Battini G, et al. IgA nephropathy, the most common cause of glomerulonephritis, is linked to 6q22-23. Nat Genet 2000 Nov;26(3):354-357.

23. Bisceglia L, Cerullo G, Forabosco P, Torres DD, Scolari F, Di Perna M, Foramitti M, Amoroso A, Bertok S, Floege J, et al. Genetic heterogeneity in Italian families with IgA nephropathy: suggestive linkage for two novel IgA nephropathy loci. Am J Hum Genet 2006 Dec;79(6):1130-1134.

24. Paterson AD, Liu XQ, Wang K, Magistroni R, Song X, Kappel J, Klassen J, Cattran D, St George-Hyslop P, Pei Y. Genome-wide linkage scan of a large family with IgA nephropathy localizes a novel susceptibility locus to chromosome 2q36. J Am Soc Nephrol 2007 Aug;18(8):2408-2415.

25. Eknoyan G, Hostetter T, Bakris GL, Hebert L, Levey AS, Parving HH, Steffes MW, Toto R. Proteinuria and other markers of chronic kidney disease: a position statement of the National Kidney Foundation (NKF) and the National Institute of Diabetes and Digestive and Kidney Diseases (NIDDK). Am J Kidney Dis 2003 Oct;42(4):617-622.

26. Gorman D, Sochett E, Daneman D. The natural history of microalbuminuria in adolescents with type 1 diabetes. J Pediatr 1999 Mar;134(3):333-337.

27. Soni SS, Gowrishankar S, Kishan AG, Raman A. Non diabetic renal disease in type 2 diabetes mellitus. Nephrology 2006 Dec;11(6):533-537.

28. Serra A, Romero R, Bayés B, Lopez D, Bonet J. Is there a need for changes in renal biopsy criteria in proteinuria in Type 2 diabetes? Diabetes Res Clin Pract 2002 Nov;58(2):149-153.

29. Prakash J, Lodha M, Singh SK, Vohra R, Raja R, Usha. Diabetic retinopathy is a poor predictor of type of nephropathy in proteinuric type 2 diabetic patients. J Assoc Physicians India 2007 Jun;55:412-416.

30. Shaw, GA.; Croker, BP. Renal biopsy as a guide to the treatment of glomerulonephritis. The therapy in nephrology and hypertension. In: Brady, HR.; Willox, CS., editors. A companion to Brenner and Rector's the kidney. 5th ed. Philadelphia, PA: W.B. Saunders; 1999. p. 85.

31. Jafar TH, Stark PC, Schmid CH, Landa M, Maschio G, Marcantoni C, de Jong PE, de Zeeuw D, Shahinfar S, Ruggenenti $\mathrm{P}$, et al. Proteinuria as a modifiable risk factor for the progression of non-diabetic renal disease. Kidney Int 2001 Sep;60(3):1131-1140.

32. Brenner BM, Cooper ME, de Zeeuw D, Keane WF, Mitch WE, Parving HH, Remuzzi G, Snapinn SM, Zhang Z, Shahinfar S. Effects of Losartan on renal and cardiovascular outcomes in patients with type 2 diabetes and nephropathy. N Engl J Med 2001 Sep;345(12):861-869.

33. Parving $\mathrm{HH}$, Lehnert $\mathrm{H}$, Bröchner-Mortensen J, Gomis R, Andersen S, Arner P; Irbesartan in Patients with Type 2 Diabetes and Microalbuminuria Study Group. The effect of irbesartan on the development of diabetic nephropathy in patients with type 2 diabetes. N Engl J Med 2001 Sep;345(12):870-878.

34. Lewis EJ, Hunsicker LG, Clarke WR, Berl T, Pohl MA, Lewis JB, Ritz E, Atkins RC, Rohde R, Raz I; for the Collaborative Study Group. Renoprotective effect of the angiotensin-receptor antagonist irbesartan in patients with nephropathy due to type 2 diabetes. N Engl J Med 2001 Sep;345(12):851-860.
35. The GISEN Group (Gruppo Italiano di Studi Epidemiologici in Nefrologia). Randomised placebo-controlled trial of effect of ramipril on decline in glomerular filtration rate and risk of terminal renal failure in proteinuric, non-diabetic nephropathy. Lancet 1997 Jun;349(9069):1857-1863.

36. Walker WG, Neaton JD, Cutler JA, Neuwirth R, Cohen JD. Renal function change in hypertensive members of the Multiple Risk Factor Intervention Trial. Racial and treatment effects. The MRFIT Research Group. JAMA 1992 Dec;268(21):3085-3091.

37. Wright JT Jr, Bakris G, Greene T, Agodoa LY, Appel LJ, Charleston J, Cheek D, Douglas-Baltimore JG, Gassman J, Glassock R, et al. Effect of blood pressure lowering and antihypertensive drug class on progression of hypertensive kidney disease: results from the AASK trial. JAMA 2002 Nov;288(19):2421-2431.

38. Jafar TH, Stark PC, Schmid CH, Landa M, Maschio G, de Jong PE, de Zeeuw D, Shahinfar S, Toto R, Levey AS, et al. Progression of chronic kidney disease: the role of blood pressure control, proteinuria, and angiotensin-converting enzyme inhibition: a patient-level meta-analysis. Ann Intern Med 2003 Aug;139(4):244-252.

39. Kidney Disease Outcomes Quality Initiative (K/DOQI). K/ DOQI clinical practice guidelines on hypertension and antihypertensive agents in chronic kidney disease. Am J Kidney Dis 2004 May;43(5 Suppl 1):S1-S290.

40. Sarafidis PA, Khosla N, Bakris GL. Antihypertensive therapy in the presence of proteinuria. Am J Kidney Dis 2007 Jan;49(1):12-26.

41. Jafar TH, Schmid CH, Landa M, Giatras I, Toto R, Remuzzi G, Maschio G, Brenner BM, Kamper A, Zucchelli P, et al. Angiotensin-converting enzyme inhibitors and progression of nondiabetic renal disease. A meta-analysis of patient-level data. Ann Intern Med 2001 Jul;135(2):73-87.

42. Praga M. Therapeutic measures in proteinuric nephropathy. Kidney Int (Suppl) 2005 Dec;68(99):S137-S141.

43. Eddy AA. Molecular insights into renal interstitial fibrosis. J Am Soc Nephrol 1996 Dec;7(12):2495-2508.

44. Nielsen S, Schmitz A, Rehling M, Mogensen CE. The clinical course of renal function in NIDDM patients with normo- and microalbuminuria. J Intern Med 1997 Feb;241(2):133-141.

45. Heart Outcomes Prevention Evaluation Study Investigators. Effects of ramipril on cardiovascular and microvascular outcomes in people with diabetes mellitus: results of the HOPE study and MICRO-HOPE substudy. Lancet 2000 Jan;355(9200):253-259.

46. Mogensen CE. Microalbuminuria predicts clinical proteinuria and early mortality in maturity-onset diabetes. N Engl J Med 1984 Feb;310(6):356-360.

47. Wang TJ, Evans JC, Meigs JB, Rifai N, Fox CS, D'Agostino RB, Levy D, Vasan RS. Low-grade albuminuria and the risks of hypertension and blood pressure progression. Circulation 2005 Mar;111(11):1370-1376.

48. Lewis EJ, Hunsicker LG, Bain RP, Rohde RD. The effect of angiotensin-converting-enzyme inhibition on diabetic nephropathy. The Collaborative Study Group. N Engl J Med 1993 Nov;329(20):1456-1462.

49. KlahrS,Levey AS, BeckGJ,Caggiula AW,Hunsicker L,KusekJW, Striker $\mathrm{G}$. The effects of dietary protein restriction and bloodpressure control on the progression of chronic renal disease. Modification of diet in Renal Disease Study Group. N Engl J Med 1994 Mar;330(13):877884. 